\title{
AKTIVITAS BERSAMA ORANG TUA-ANAK DAN PERLINDUNGAN ANAK MENINGKATKAN KESEJAHTERAAN SUBJEKTIF ANAK
}

\author{
Vivi Irzalinda ${ }^{\star *}$, Herien Puspitawati ${ }^{2}$, Istiqlaliyah Muflikhati ${ }^{2}$ \\ ${ }^{1}$ Program Studi IImu Keluarga dan Perkembangan Anak, Sekolah Pascasarjana, Institut Pertanian Bogor, \\ Bogor 16680, Indonesia \\ ${ }^{2}$ Departemen IImu Keluarga dan Konsumen, Fakultas Ekologi Manusia, Institut Pertanian Bogor, \\ Bogor 16680, Indonesia
}

*)E-mail: tazaka_88@yahoo.com

\begin{abstract}
Abstrak
Dalam mencapai kesejahteraan anak yang lebih baik, dunia internasional maupun Indonesia telah sepakat untuk meningkatkan berbagai upaya dalam perlindungan anak, termasuk meningkatkan kapasitas orang tua dalam melakukan pengasuhan yang lebih baik. Aktivitas bersama antara orang tua dan anak merupakan salah satu indikator penting dalam menciptakan pengasuhan yang berkualitas. Tujuan dari penelitian ini adalah untuk menganalisis aktivitas bersama antara orang tua-anak dan perlindungan anak serta pengaruhnya terhadap kesejahteraan subjektif anak. Penelitian ini menggunakan desain cross sectional. Lokasi dipilih secara purposive di Desa Ciputri, Kecamatan Pacet dan Desa Sindang Jaya, Kecamatan Cipanas, Kabupaten Cianjur, Provinsi Jawa Barat. Sebanyak seratus dua puluh keluarga dipilih secara purposive diantara keluarga petani. Temuan menunjukkan bahwa aktivitas bersama orang tua-anak berada pada tingkat kategori rendah. Perlindungan anak dalam aspek fisik berada dalam kategori rendah, sementara perlindungan lingkungan anak berada dalam kategori tinggi. Kesejahteraan subjektif anak berada pada kategori tinggi. Variabel independen yang memengaruhi kesejahteraan subjektif anak adalah aktivitas bersama orang tua-anak dan perlindungan fisik. Oleh karenanya, direkomendasikan untuk dilakukan sosialisasi bahwa perlindungan anak dan aktivitas bersama orang tua-anak sangat diperlukan untuk meningkatkan kesejahteraan subjektif anak di kalangan keluarga petani.
\end{abstract}

Kata kunci: aktivitas bersama orang tua-anak, kesejahteraan subjektif anak, perlindungan anak

\section{Time-Shared Activities among Parent-Children and Child Protection Improve Children's Subjective Well-being}

\begin{abstract}
In achieving better child well-being, international and Indonesia have agreed to increase efforts in the protection of children, including increasing the capacity of parents to perform better parenting. Time-shared activities among parent and children are important factor to create qualified parenting. The purpose of this study was to analyze the time-shared activities among parents-children and child protection in the family and its influence on children's subjective well-being. This study was a cross-sectional design. Study sites were selected purposively at Ciputri Village, Pacet Sub District; and Sindang Jaya Village, Cipanas Sub District, Cianjur DistrictWest Java Province. One hundred and twenty families were purposively chosen among farmer families. Findings showed that the time-shared activities among parents-children were categorized as in low level. Child protection in physical aspect was in the low category but the environmental protection of child was in high category. Children's subjective well-being was in the high category. Independent variables that influenced the children's subjective well-being were time-shared activities among parents-children and physical protection. It was recommended to conduct socialization about the importance of child protection and time-shared activities among parents-children on improving children's subjective well-being among farmer families.
\end{abstract}

Keywords: child protection, children's subjective well-being, time-shared activities among parents-children

\section{PENDAHULUAN}

Kualitas bangsa di masa depan ditentukan
oleh kualitas anak-anak saat ini. Perkembangan anak adalah hasil interaksi antara lingkungan anak-anak dimana mereka tinggal. Lingkungan mikrosistem adalah lingkungan yang dihabiskan anak dalam waktu panjang, antara lain keluarga, teman sebaya, sekolah dan tetangga (Bronfenbrenner, 1979). Kualitas anak ditentukan oleh interaksi yang terjadi antara ibu dan anak dalam sebuah keluarga. Interaksi orang tua-anak yang terjadi di dalam keluarga sebagai lingkungan terdekat anak akan sangat memengaruhi kehidupan anak (Hastuti et al., 2008). Aktivitas bersama 
orang tua dan anak merupakan bagian dari interaksi orang tua dan anak.

Kesejahteraan menggambarkan kualitas kehidupan anak. Kesejahteraan anak penting untuk diukur sebagai bentuk identifikasi dini masalah, mengetahui apa yang terjadi dan mengapa hal tersebut terjadi, serta memberikan perhatian untuk tindakan preventif terhadap kualitas anak (Thompson \& Aked, 2009). Kesejahteraan anak dipengaruhi oleh situasi dan lingkungan dimana anak-anak berkembang. Lingkungan yang baik memberikan dukungan yang tepat untuk anak-anak untuk berkembang. Penelitian Carlsson et al. (2011) menemukan bahwa faktor yang memengaruhi kesejahteraan subjektif anak adalah jumlah teman dekat, bebas dari bullying, serta aktivitas bersama dengan orang tua.

Anak secara umum merupakan tanggung jawab keluarga, sehingga keluarga bertanggung jawab untuk melindungi anak. Perlindungan anak perlu karena anak merupakan amanat dari Tuhan Yang Maha Kuasa yang berhak mendapatkan perlindungan dari segala bentuk yang mengganggu atau menolak hak-hak anak seperti kekerasan dan diskriminasi (Handayani, 2013). Masih banyaknya keluarga maupun masyarakat yang menganggap hukuman fisik dan kekerasan fisik terhadap anak sebagai norma menjadi hambatan untuk meningkatkan perlindungan anak. Sebagai generasi penerus bangsa, anak menentukan masa depan pemimpin bangsa.

Petani holtikultura menggunakan berbagai pestisida untuk mengurangi kerugian dari hama penyakit. Meskipun pestisida berkontribusi pada produksi pertanian, namun banyak penelitian menunjukkan pestisida merugikan kesehatan manusia dan ekosistem (Tadesse \& Asferachew, 2008). Penelitian terdahulu menyatakan paparan pestisida pada awal kehidupan anak dapat mengubah pola perkembangan anak, dan berpengaruh pada disfungsi kesehatan dan beresiko penyakit seusia hidup. Paparan bahan kimia diidentifikasi berpotensi berbahaya bagi perkembangan awal anak diantaranya adalah radiasi ozon (Newcombe \& McGregor, 1971), pestisida organoklorin (Longnecker et al., 2002), polusi udara di luar ruangan (Trasande, Landrigan, \& Schechter, 2005), dan pestisida tertentu lainnya (Gray et al., 2001), terutama insektisida organofosfat (NRC, 1993).

Anak-anak lebih rentan untuk terkena paparan pestisida (NRC, 1993). Hal ini karena anak-anak menghirup dosis pestisida yang relatif lebih besar dibandingkan orang dewasa bila terkena pestisida di lingkungan, karena anak-anak bernapas dalam volume yang lebih besar dan memiliki permukaan kulit yang lebih besar, rentan terhadap efek racun dari bahan kimia karena tubuh mereka lebih kecil dan masih berkembang, sistem kekebalan tubuh anak-anak belum sepenuhnya berkembang hingga usia remaja, hati, dan ginjal anak-anak tidak mampu untuk mengeluarkan racun dan bahan kimia tertentu secepat orang dewasa (NRC, 1993). Hal ini memberikan kontribusi terhadap toksisitas yang lebih besar dari beberapa zat pada anak-anak. Hal ini menyebabkan anak-anak beresiko terkena penyakit kulit akibat pestisida, baik di dalam maupun di luar ruangan, karena perilaku dan gaya hidup mereka sering menyentuh banyak permukaan yang terkontaminasi dengan residu pestisida (Lewis, 1994; Fenske, 1990; Zartarian, 1998), perilaku anak sering tangan ke mulut, menelan debu atau tanah yang terkontaminasi dengan jumlah yang relatif besar (Lewis, 1994; Hawley, 1985), mereka duduk, merangkak atau berguling di tanah, atau terhirup udara yang banyak pestisida (Zweiner \& Ginsburg, 1988; Fenske, 1990).

Keluarga petani memiliki resiko besar terhadap bahaya pestisida. Penggunaan dan penyimpanan yang tidak aman akan menyebabkan dampak buruk bagi keluarga terutama anak. Penelitian ini secara umum bertujuan untuk menganalisis aktivitas bersama antara orang tua dan anak pada keluarga petani serta perlindungan anak yang dilakukan keluarga petani dan pengaruhnya terhadap kesejahteraan subjektif anak keluarga petani. Secara khusus penelitian ini bertujuan untuk menganalisis aktivitas bersama antara orang tua dan anak pada keluarga petani dan perlindungan anak yang dilakukan keluarga petani, menganalisis kesejahteraan subjektif anak keluarga petani, dan menganalisis pengaruh aktivitas bersama orang tua-anak dan perlindungan anak terhadap kesejahteraan subjektif anak.

\section{METODE}

Penelitian ini menggunakan desain cross sectional. Data penelitian ini merupakan bagian penelitian "Gender and Integrated Pest Management". Lokasi dipilih secara purposive yaitu Desa Sindangjaya, Kecamatan Cipanas dan Desa Ciputri, Kecamatan Pacet, Kabupaten Cianjur yang merupakan lokasi Gender IPM-CRSP yang didanai oleh USAID. Pemilihan lokasi dipilih dengan pertimbangan Kabupaten Cianjur merupakan salah satu 
daerah sentra produksi berbagai sayuran. Penelitian dilaksanakan pada bulan Juli sampai bulan November 2013.

Populasi penelitian ini adalah keluarga petani yang terdiri atas ayah dan ibu serta minimal 1 orang anak kelas 4 sampai 6 SD yang tinggal di Desa Sindangjaya, Kecamatan Cipanas dan Desa Ciputri, Kecamatan Pacet, Kabupaten Cianjur. Responden penelitian adalah ibu dan anak. Penentuan responden dilakukan secara purposive dengan ibu yang memiliki anak kelas 4 sampai $6 \mathrm{SD}$, berasal dari keluarga lengkap atau single-parent (tidak ada suami), dan bersedia untuk dijadikan sampel. Jumlah contoh adalah 120 keluarga.

Data primer yang dikumpulkan diperoleh dengan wawancara (kuesioner) terstruktur adalah: (1) karakteristik anak, yang terdiri usia dan jenis kelamin, (2) karakteristik keluarga, yang terdiri atas usia ayah, usia ibu, pendidikan ayah, pendidikan ibu, jumlah anggota keluarga, pendapatan dan pekerjaan, (3) aktivitas bersama orang tua dan anak, (4) perlindungan anak yang terdiri atas fisik dan lingkungan dan (5) kesejahteraan subjektif anak. Nilai Cronbach's alpha yang dihasilkan dari uji reliabilitas yaitu aktivitas bersama orang tuaanak $(0,779)$, perlindungan anak $(0,758)$ dan kesejahteraan subjektif anak $(0,857)$.

Cara pengukuran variabel karakteristik keluarga dan anak yaitu usia orang tua digolongkan ke dalam 3 kelompok terdiri atas kelompok usia 20-40 tahun (dewasa awal), 4160 tahun (dewasa madya), 61 keatas (dewasa akhir) (Papalia \& Olds, 2001). Usia anak digolongkan atas 3 kelompok yaitu usia 10 tahun, 11 tahun, dan 12 tahun (Papalia \& Olds, 2001). Lama pendidikan orang tua adalah lama pendidikan dalam tahun yang ditempuh, yang terdiri atas 0 tahun, 1-6 tahun, 7-9 tahun, 10-12 tahun, 13-16 tahun, dan $\geq 16$ tahun. Pekerjaan suami adalah pekerjaan tetap dan pekerjaan tambahan. Besar keluarga digolongkan dalam tiga kategori, yaitu keluarga kecil ( $\leq 4$ orang), keluarga sedang (5-7 orang), dan keluarga besar ( $>7$ orang).

Pendapatan keluarga adalah jumlah pendapatan pokok dan sampingan suami, ditambah pendapatan anak dan anggota keluarga lain yang rutin diberikan kepada keluarga ibu. Berdasarkan upah minimum ratarata, pendapatan dan pengeluaran total keluarga per bulan dibagi kedalam empat kategori yaitu lebih kecil atau sama dengan Rp970.000, Rp970.001 sampai Rp1.940.000, Rp1.940.001 sampai Rp2.910.000,
Rp2.910.001 sampai Rp3.880.000, dan lebih besar dari Rp3.880.001. Pengkategorian pendapatan dan pengeluaran per kapita per bulan berdasarkan Garis Kemiskinan Kabupaten Cianjur tahun 2013 dikategorikan rendah apabila lebih kecil dari Rp268.251.

Pengukuran variabel aktivitas bersama antara orang tua dan anak didasarkan atas 12 pertanyaan baik pertanyaan untuk ibu maupun untuk ayah. Setiap butir pertanyaan disediakan dua jawaban, yaitu tidak diberi skor 0 , dan ya diberi skor 1. Pengukuran perlindungan anak didasarkan atas 24 pertanyaan. Masing-masing pertanyaan diberi skala dan nilai dengan ketentuan: tidak diberi skor 0 , ya diberi skor 1 . Pengukuran tingkat kesejahteraan subjektif anak didasarkan atas 28 pertanyaan. Masingmasing pertanyaan diberi skala dan nilai dengan ketentuan: tidak puas diberi skor 1, cukup puas diberi skor 2 , dan puas diberi skor 3 , sehingga total skor 28-84. Skor masingmasing dimensi setiap variabel dijumlahkan sehingga diperoleh skor total dan kemudian masing-masing skor ditransformasikan ke dalam bentuk indeks, dengan rumus di bawah ini. Hasil indeks dikelompokkan menjadi tiga kategori yaitu rendah $(\leq 50,0)$, sedang $(50,1$ $75,0)$, dan tinggi $(>75,1)$.

Data yang diperoleh melalui wawancara, pengukuran dan observasi diolah dengan proses yang mencakup transfer, coding, editing, entry data, cleaning data, dan analisis data. Analisis data dilakukan secara deskriptif dan inferensial. Data primer yang dianalisis secara deskripsif mencakup karakteristik anak, karakteristik keluarga, persepsi orang tua, aktivitas bersama, perlindungan anak, dan kesejahteraan subjektif anak. Data inferensial yaitu uji pengaruh, uji regresi linear berganda. Uji regresi linear berganda digunakan untuk menguji variabel-variabel yang berpengaruh terhadap kesejahteraan subjektif anak. Model regresi linear berganda pada penelitian ini adalah:

$$
\begin{aligned}
Y= & \beta 0+\beta 1 X 1+\beta 2 X 2+\beta 3 \times 3+\beta 4 X 4+ \\
& \beta 5 \times 5+\beta 6 \times 6+\beta 7 \times 7+\beta 8 \times 8+\beta 9 \times 9+ \\
& \beta 10 \times 10+\varepsilon
\end{aligned}
$$

Keterangan:

$\mathrm{Y}=$ Kesejahteraan subjektif anak

$\mathrm{X} 1=$ Jenis kelamin anak

X2 = Usia anak

$\mathrm{X} 3=$ Usia ibu

X4 = Lama pendidikan ibu

$\mathrm{X} 5=$ Lama pendidikan ayah

$\mathrm{X} 6$ = Jumlah anggota keluarga

X7 = Aktivitas bersama orang tua-anak

$\mathrm{X} 8=$ Pendapatan keluarga

$\mathrm{X} 9=$ Perlindungan fisik

$\mathrm{X} 10=$ Perlindungan lingkungan 


\section{HASIL}

\section{Karakteristik Anak dan Keluarga}

Persentase terbesar $(31,7 \%)$ anak berusia 11 tahun dengan rentang usia anak yaitu 9-14 tahun. Persentase terbesar $(50,0 \%)$ usia ayah pada rentang 20-40 tahun (usia dewasa awal). Sementara itu, persentase terbesar (72,5\%) usia ibu berada pada rentang 20-40 tahun. Dengan demikian, usia ibu termasuk dalam kategori dewasa awal. Rata-rata lama ayah menempuh pendidikan formal adalah 6 tahun, dengan rentang 0-12 tahun. Selain itu, rata-rata lama ibu menempuh pendidikan formal adalah 5,88 tahun dengan rentang 0-12 tahun. Ratarata jumlah anggota keluarga contoh adalah 5 orang. Contoh bekerja sebagai petani pemilik $(91,7 \%)$ dan buruh tani $(8,3 \%)$.

\section{Pendapatan Keluarga}

Garis Upah Minimum Rata-rata (UMR) Kabupaten Cianjur tahun 2013 adalah Rp970.000,00. Berdasarkan hasil analisis diketahui bahwa sebanyak 37,5 persen keluarga menyatakan mememiliki pendapatan di bawah UMR. Rata-rata pendapatan keluarga adalah Rp2.359.394,00 per bulan dengan rentang Rp100.000,00-Rp40.000.000,00 per bulan. Menurut BPS (2013), batas garis kemiskinan masyarakat Kabupaten Cianjur adalah Rp268.251,00 per kapita per bulan. Rata-rata pendapatan keluarga per kapita adalah Rp445.465,00/bulan, dengan rentang Rp20.000,00-Rp8.575.000,00/bulan. Berdasarkan garis kemiskinan Kabupaten Cianjur maka diketahui bahwa lebih dari setengah keluarga $(58,3 \%)$ termasuk keluarga miskin.

\section{Aktivitas Bersama}

Aktivitas bersama antara orang tua dan anak terdiri atas aktivitas bersama antara ibu dan anak, dan aktivitas bersama antara ayah dan anak. Aktivitas bersama antara ibu dan anak yang sering dilakukan adalah makan pagi bersama $(51,7 \%)$, saat ibu bekerja di kebun $(69,2 \%)$, dan anak akan berangkat sekolah $(53,3 \%)$. Sementara itu, aktivitas yang tidak pernah dilakukan bersama antara ibu dan anak adalah makan siang bersama (85,8\%), makan malam bersama $(52,5 \%)$, menjelang tidur $(66,7 \%)$, setelah beribadah $(85,8 \%)$, menonton TV $(62,5 \%)$, menemani anak belajar (52,5\%), bermain bersama $(63,3 \%)$, anak pulang sekolah $(53,3 \%)$. Bila dikategorikan, persentase terbesar $(61,7 \%)$ aktivitas bersama antara ibu dan anak berada pada kategori rendah (Tabel 1).
Tabel 1 Sebaran aktivitas bersama antara orang tua dan anak

\begin{tabular}{|c|c|c|}
\hline Kategori & Jumlah & Persentase \\
\hline \multicolumn{3}{|c|}{ Aktivitas bersama antara ibu dan anak } \\
\hline Rendah & 74 & 61,7 \\
\hline Sedang & 43 & 35,8 \\
\hline Tinggi & 3 & 2,5 \\
\hline Total & 120 & 100,0 \\
\hline $\begin{array}{l}\text { Rata-rata } \pm S t a n d a r \\
\text { deviasi }\end{array}$ & \multicolumn{2}{|c|}{$41,0 \pm 20,2$} \\
\hline \multicolumn{3}{|c|}{ Aktivitas bersama antara ayah dan anak } \\
\hline Rendah & 93 & 77,5 \\
\hline Sedang & 26 & 21,7 \\
\hline Tinggi & 1 & 0,8 \\
\hline Total & 120 & 100,0 \\
\hline $\begin{array}{l}\text { Rata-rata } \pm \text { Standar } \\
\text { deviasi }\end{array}$ & \multicolumn{2}{|c|}{$33,3 \pm 20,0$} \\
\hline \multicolumn{3}{|c|}{ Aktivitas bersama antara orang tua dan anak } \\
\hline Rendah & 92 & 76,7 \\
\hline Sedang & 26 & 21,7 \\
\hline Tinggi & 2 & 1,7 \\
\hline Total & 120 & 100,0 \\
\hline $\begin{array}{l}\text { Rata-rata } \pm \text { Standar } \\
\text { deviasi }\end{array}$ & \multicolumn{2}{|c|}{$37,2 \pm 19,1$} \\
\hline
\end{tabular}

Hasil penelitian menunjukkan aktivitas bersama antara ayah dan anak yang sering dilakukan adalah saat ayah bekerja di kebun $(72,5 \%)$, dan anak akan berangkat sekolah $(51,7 \%)$. Sementara itu, aktivitas yang tidak dilakukan bersama ayah dan anak adalah makan pagi bersama $(69,2 \%)$, makan siang bersama $(93,3 \%)$, makan malam bersama $(55,8 \%)$, menjelang tidur $(75,8 \%)$, setelah beribadah $(85,8 \%)$, menonton TV $(70,0 \%)$, menemani anak belajar $(68,3 \%)$, bermain bersama $(65,0 \%)$, dan anak pulang sekolah $(74,2 \%)$. Bila dikategorikan, persentase terbesar $(77,5 \%)$ aktivitas ayah-anak pada kategori rendah (Tabel 1). Hal tersebut menandakan bahwa anak tidak banyak menghabiskan kegiatan bersama ayah mereka. Secara tradisional, dalam keluarga lengkap ibu akan berperan sebagai pengasuh utama dan ayah sebagai pencari nafkah. Partisipasi ayah dalam hal pemberian makan lebih rendah daripada ibu, tetapi ayah cenderung lebih suka untuk menstimulus dan bermain secara fisik, sedangkan ibu lebih menstimulus secara verbal (Parke \& Tinsley, 1981).

Hasil penelitian menunjukkan bahwa persentase terbesar $(76,7 \%)$ aktivitas bersama antara orang tua dan anak pada klasifikasi rendah (Tabel 1). Hasil pengamatan diketahui bahwa anak jarang menghabiskan waktu bersama orang tuanya. Anak lebih banyak menghabiskan waktunya dengan teman sebayanya. Hasil juga menunjukkan bahwa ayah menghabiskan waktu yang lebih sedikit dengan anak mereka sewaktu masih anak-anak dibanding dengan yang dilakukan oleh ibu. 
Saat ayah melakukan aktivitas dengan anak maka kegiatan yang lebih banyak dilakukan adalah kegiatan yang melibatkan fisik dan kegiatan luar ruangan.

\section{Perlindungan Anak}

Perlindungan anak terdiri atas perlindungan fisik dan perlindungan lingkungan. Perlindungan fisik adalah kegiatan orang tua memenuhi kebutuhan fisik anak dan melindungi dari kekerasan fisik. Hasil penelitian menunjukkan bahwa umumnya orang tua memberikan perlindungan fisik kepada anak dengan baik. Perlindungan fisik yang baik dari orang tua dapat terlihat, yaitu anak diberikan sandal/alas kaki ketika keluar rumah $(96,7 \%)$, anak diajarkan cuci tangan setelah buang air besar $(90,0 \%)$, diajarkan tidak mudah berbicara dengan orang asing $(79,2 \%)$, diajarkan persiapan menstruasi bagi anak perempuan dan mimpi basah bagi anak laki-laki $(60,8 \%)$, ada sekat antar kamar tidur anak dengan orang tua $(80,8 \%)$, dan diberikan bimbingan agama $(93,3 \%)$. Namun, orang tua menyatakan masih menghukum anak jika malakukan kesalahan, seperti mencubit $(96,7 \%)$, memukul $(76,7 \%)$, namun anak tidak pernah ditampar keras dengan tangan oleh orang tua $(96,7 \%)$. Selain itu, anak juga tidak diajarkan untuk berhati-hati dengan media sosial $(64,2 \%)$. Umumnya, anak sekolah dasar di desa belum menggunakan media sosial. Apabila diklasifikasikan maka diketahui bahwa persentase terbesar $(65,8 \%)$ responden menyatakan memiliki perlindungan fisik pada kategori tinggi. Sebaran keluarga, nilai rata-rata, dan standar deviasi untuk perlindungan keluarga, baik untuk perlindungan fisik maupun perlindungan lingkungan disajikan pada Tabel 2.

Tabel 2 Sebaran keluarga, nilai rata-rata, dan standar deviasi perlindungan anak (perlindungan fisik dan perlindungan lingkungan)

\begin{tabular}{|c|c|c|}
\hline Kategori & Jumlah & Persentase \\
\hline \multicolumn{3}{|l|}{ Perlindungan fisik } \\
\hline Rendah & 5 & 4,2 \\
\hline Sedang & 36 & 30,0 \\
\hline Tinggi & 79 & 65,8 \\
\hline Total & 120 & 100,0 \\
\hline $\begin{array}{l}\text { Rata-rata } \pm \text { Standar } \\
\text { deviasi }\end{array}$ & \multicolumn{2}{|c|}{$81,11 \pm 13,3$} \\
\hline \multicolumn{3}{|l|}{ Perlindungan lingkungan } \\
\hline Rendah & 58 & 48,3 \\
\hline Sedang & 23 & 19,2 \\
\hline Tinggi & 39 & 32,5 \\
\hline Total & 120 & 100,0 \\
\hline $\begin{array}{l}\text { Rata-rata } \pm \text { Standar } \\
\text { deviasi }\end{array}$ & \multicolumn{2}{|c|}{$59,1 \pm 27,6$} \\
\hline
\end{tabular}

Perlindungan lingkungan adalah kegiatan melindungi anak dari bahaya lingkungan, contohnya perlindung-an dari bahaya pestisida terhadap anak. Hasil penelitian menunjukkan bahwa belum banyak perlindungan lingkungan yang dilakukan orang tua pada anak. Orang tua hanya melindungi anak dengan cara diajarkan untuk tidak bermain dengan alat pestisida $(50,8 \%)$, ketika orang tua sedang menyemprot menggunakan pestisida anak dilarang mendekat $(65,8 \%)$, orang tua mengawasi anak bermain dilahan pertanian sambil bekerja $(60,0 \%)$. Namun, orang tua belum memperkenalkan bahaya pestisida $(62,5 \%)$, menjelaskan fungsi pestisida (65,0\%), memberitahu anak bahaya atau penyakit yang ditimbulkan dari pestisida $(51,7 \%)$, menjelaskan bahaya pestisida ter-hadap kesehatan $(50,0 \%)$ dan mengajarkan anak menggunakan alat pestisida dengan hati-hati $(50,0 \%)$. Sementara itu, perlindungan orang tua pada anak terhadap bahaya pestisida sangat penting. Anak-anak sangat rentan terhadap efek racun dari bahan kimia banyak karena tubuh mereka lebih kecil dan masih berkembang (NRC, 1993). Bila diklasifikasikan maka diketahui bahwa persentase terbesar $(48,3 \%)$ responden menyatakan memiliki per-lindungan lingkungan yang rendah (Tabel 2).

\section{Kesejahteraan Subjektif Anak}

Indikator kesejahteraan subjektif anak terdiri atas kepuasan rumah, kepuasan materi, kepuasan terhadap hubungan interpersonal, kepuasan terhadap area tempat tinggal, kepuasan terhadap kesehatan, kepuasan terhadap sekolah, dan kepuasan personal (Huebner, 1991; Cummins et al., 2003). Hasil penelitian menunjukkan bahwa umumnya responden memiliki kategori "puas" yang tinggi pada semua indikator kesejahteraan subjektif anak. Namun, terdapat beberapa kepuasan yang memiliki nilai terendah, yaitu nilai di sekolah $(57,5 \%)$, penyimpanan pestisida/alat penyemprot/pupuk kimia di rumah $(64,2 \%)$ dan di kamar sendiri $(69,2 \%)$. Persentase terbesar $(95,8 \%)$ anak menyatakan memiliki kesejahteraan subjektif pada kategori tinggi (Tabel 3).

Tabel 3 Sebaran kategori kesejahteraan subjektif anak

\begin{tabular}{lrr}
\hline Kategori & Jumlah & Persentase \\
\hline Rendah & 0 & 0,0 \\
Sedang & 5 & 4,2 \\
Tinggi & 115 & 95,8 \\
\hline Total & 120 & 100,0 \\
\hline $\begin{array}{l}\text { Rata-rata } \pm \text { Standar } \\
\text { deviasi }\end{array}$ & $91,9 \pm 7,5$ & \\
\hline
\end{tabular}




\section{Pengaruh Karakteristik Keluarga, Aktivitas Bersama, dan perlindungan Anak terhadap Kesejahteraan Subjektif Anak}

Model untuk menganalisis pengaruh karakteristik keluarga, aktivitas bersama, dan perlindungan anak terhadap kesejahteraan subjektif anak memiliki koefisien determinasi sebesar 0,209 (Tabel 4). Nilai ini mengunjukkan bahwa variabel-variabel yang disusun dalam model dapat menjelaskan 20,9\% pengaruhnya terhadap kesejahteraan subjektif anak. Faktorfaktor yang berpengaruh signifikan terhadap kesejahteraan subjektif anak adalah aktivitas bersama antara orang tua dan anak $(\beta=0,350$, $p=0,01)$ anak dan perlindungan fisik $(\beta=0,226$, $p=0,05)$. Setiap peningkatan aktivitas bersama orang tua-anak satu satuan dapat meningkatkan kesejahteraan subjektif anak sebesar 0,350 satuan. Setiap peningkatan perlindungan fisik satu satuan juga dapat meningkatkan kesejahteraan subjektif anak sebesar 0,226 satuan. Dengan demikian, kesejahteraan subjektif anak meningkat dengan bertambahnya aktivitas bersama orang tua dan anak dan juga bertambahnya perlindungan fisik.

Tabel 4 Koefisien regresi karakteristik keluarga, investasi anak dan perlindungan anak terhadap kesejehteraan subjektif anak

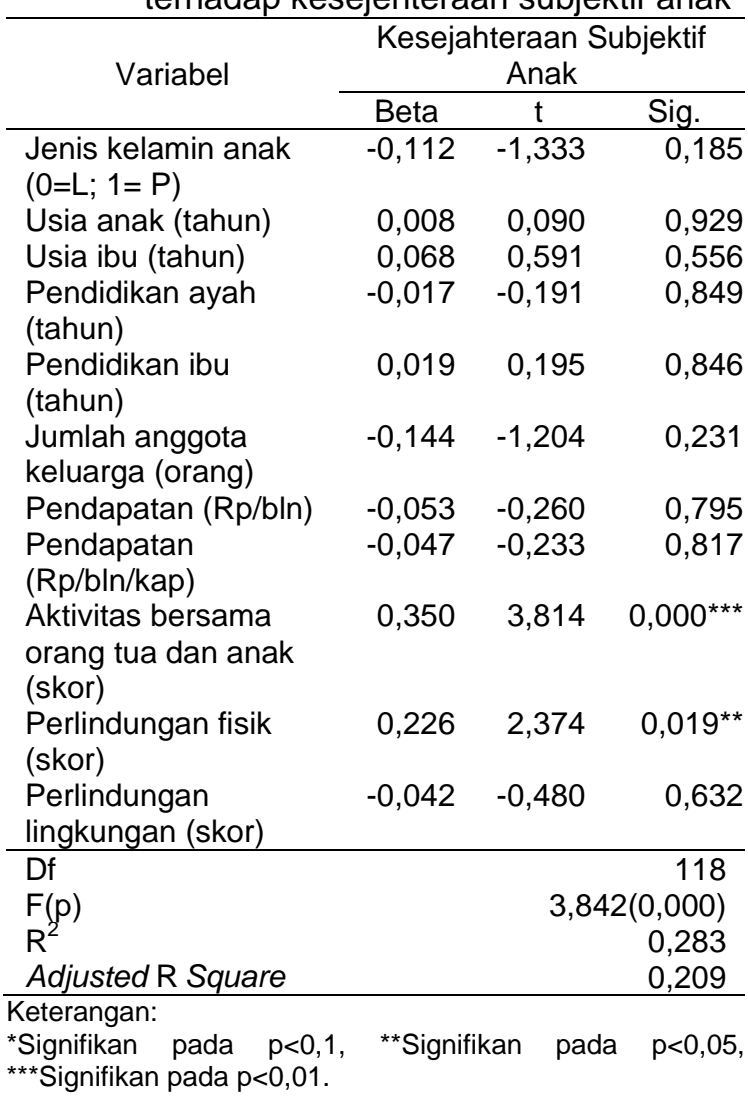

\section{PEMBAHASAN}

Hasil penelitian menunjukkan bahwa kesejahteraan subjektif anak dipengaruhi oleh aktivitas bersama orang tua-anak. Aktivitas bersama antara orang tua dan anak yang baik akan meningkatkan kesejahteraan anak. Penelitian ini senada dengan Carlsson, Lampi, \& Martinsson (2011) yang menyatakan bahwa faktor yang memengaruhi kesejahteraan subjektif anak adalah jumlah teman dekat, bebas dari bullying, serta meluangkan waktu dan berbincang dengan orang tua. Selain itu, aktivitas bersama orang tua-anak penting untuk perkembangan anak, yaitu merangsang stimulus perkembangan anak, media belajar, menstimulasi kemampuan sensori-motorik, kognitif, sosial-emosional dan bahasa anak (Wong et al., 2008),

Selain itu, penelitian ini menunjukkan bahwa kesejahteraan subjektif anak dipengaruhi oleh perlindungan fisik. Semakin baik perlindungan fisik yang diberikan orang tua maka semakin tinggi kesejahteraan subjektif anak. Contoh perlindungan fisik yang diberikan orang tua adalah menanamkan ilmu agama sejak dini. Berdasarkan hasil pengamatan dilapang, orang tua mendidik dan melindungi anak dengan membekali ilmu agama yang kuat. Hal ini dapat dilihat pada aktivitas anak untuk mengaji yang cukup padat setiap harinya. Aktivitas mengaji dilakukan tiga kali setiap harinya, yaitu pagi, sore dan malam. Selain itu, anak dibekali dengan seni dan budaya daerah setempat. Hal ini dapat dilihat dengan adanya sanggar budaya dan seni setiap malam minggu. Kegiatan sanggar budaya dan seni berupa pencak silat, angklung, drama komedi, dan gendang. Orang tua menyatakan hal ini cukup efektif untuk menyalurkan bakat anak dan mencegah anak dalam pergaulan bebas. Aquilino (1986), Clark dan Ladd (2000) menyatakan bahwa pola asuh yang jelas terkait dengan kualitas anak. Hasil penelitian ini juga senada dengan Rickman \& Davidson, (1994); Furnham \& Cheng, (1999) yang menunjukkan bahwa kepribadian orang tua juga dapat berkontribusi untuk kesejahteraan anak.

Hasil penelitian menyatakan orang tua mencubit atau memukul kepada anak jika melakukan kesalahan. Hal ini akan berdampak buruk bagi anak. Pengalaman menyaksikan, mendengar, mengalami kekerasan dalam lingkup keluarga menimbulkan pengaruhpengaruh negatif pada keamanan, stabilitas hidup dan kesejahteraan anak (Carlson, 2000). Anak yang mengalami kekerasan fisik juga berdampak negatif terhadap perkembangan 
emosi, yang sering berlanjut sampai remaja atau dewasa (Messman-Morre, Walsh, \& DiLillo, 2010). Kekerasan fisik anak dapat melemahkan emosional dan masalah perilaku yang dapat bertahan sampai dewasa dan hubungan sosial ke masa depan, termasuk hubungan orang tuaanak.

Hasil analisis diketahui bahwa orang tua mendukung kegiatan pendidikan anak seperti menamani belajar dan memberikan pendidikan agama sejak dini. Hal ini senada dengan Pailhe \& Solaz (2006) menyatakan bahwa orang tua berkontribusi pada pendidikan anak-anak dan meluangkan waktu orang tua dengan anak. Dari hasil analisis menyatakan bahwa orang tua menemani belajar anak. Hal ini senada dengan Cooper et al. (1998) menyatakan orang tua menciptakan lingkungan belajar dengan menyediakan tempat belajar dan menentukan waktu makan, tidur dan pekerjaan rumah serta belajar dan menemani anak belajar.

Selain itu, orang tua memuji anak ketika anak mendapatkan hasil yang baik di sekolah. Hasil ini konsisten dengan Miserandino (1996) menyatakan orang tua memotivasi anaknya secara ekstrinsik maupun intrinsik. Orang tua yang menggunakan cara ekstrinsik yaitu dengan cara memberikan uang atau barang apabila sang anak mendapatkan peringkat yang bagus atau menghukumnya apabila peringkat sang anak buruk. Orang tua yang menggunakan cara intrinsik yaitu dengan cara memuji kemampuan atau kerja keras mereka. Motivasi intrinsik akan lebih efektif untuk pembelajaran anak.

\section{SIMPULAN DAN SARAN}

Sebagian besar aktivitas bersama ibuanak dan aktivitas bersama ayah-anak berada pada kategori rendah. Perlindungan anak yang dilakukan orang tua yaitu perlindungan fisik pada kategori tinggi, sedangkan perlindungan lingkungan pada kategori rendah. Kesejahteraan subjektif anak pada kategori sangat tinggi. Namun masih terdapat beberapa kesejahteraan yang memiliki nilai terendah, yaitu nilai di sekolah, penyimpanan pestisida atau alat penyemprot atau pupuk kimia di rumah, dan kamar sendiri. Faktor yang memengaruhi kesejahteraan subjektif anak adalah aktivitas bersama antara orang tua-anak, dan pelindungan fisik. Jenis kelamin dan usia ayah berpengaruh signifikan negatif terhadap kesejahteraan subjektif anak. Usia ibu, aktivitas bersama orang tua-anak, perlindungan fisik memiliki pengaruh signifikan positif terhadap kesejahteraan subjektif anak.
Saran dari penelitian ini adalah pertama, perlunya sosialisasi dan pendampingan dari pemerintah atau perguruan tinggi kepada keluarga dan masyarakat tentang manfaat aktivitas bersama orang tua-anak. Kedua, perlu adanya sosialisasi dan pendampingan kepada keluarga, sekolah dan masyarakat lingkungan pertanian terkait pentingnya perlindungan lingkungan anak di keluarga petani.

\section{UCAPAN TERIMAKASIH}

Penulis mengucapkan terimakasih kepada project Gender-CRSP didanai USAID dan IPB Virginia Tech. Hasil penelitian yang disajikan ini menggunakan sebagian data penelitian hasil kerja sama ketiga institusi tersebut.

\section{DAFTAR PUSTAKA}

Aquilino, W. S. (1986). Children's perceptions of marital interaction. Child Study Journal, 16, 159-172.

[BPS] Badan Pusat Statistik. (2013). Data Informasi Kemiskinan 2012-2013. Jakarta, ID: BPS Pusat.

Bronfenbrenner, U. (1979). The ecology of human development: Experiments by nature and design. Cambridge, MA, US: Harvard University Press.

Carlson, B. E. (2000). Children exposed to intimate partner violence: Research findings and implications for intervention. Trauma, Violence and Abuse, 1, 321-340.

Carlsson, F., Lampi, E., Li, W., \& Martinsson, P. (2011). Subjective well-being among preadolescents. Journal Departement of Economics: University of Gothenburg.

Clark, K. E. \& Ladd, G.W. (2000). Connectedness and autonomy support in parent-child relationships: Links to children's socioemotional orientation and peer relationships. Developmental Psychology, 36, 485-498.

Cooper, H. H., Lindsay, J. J., Nye, B., \& Greathouse, S. (1998). Relationships between attitudes about homework, the amount of homework assigned and completed, and student achievement. Journal of Educational Psychology, 90, 7083.

Cummins, R., Eckersley, R., Pallant, J., Van Vugt, J., \& Misajon, R. (2003). Developing a national index of subjective wellbeing: the Australian Unity Wellbeing Index, Social Indicators Research, 64, 159-190. 
Fenske. (1990). Potential exposure and health risks of infants following indoor residential pesticide applications. American Journal of Public Health, 80(6), 689-693.

Furnham, A., \& Cheng, H. (1999). Personality and predictors of mental health and happiness in the east and West. Personality and Individual Differences, 27, 395-403.

Gray, L. E., Ostby, J., Furr, J., Wolf, C. J., Lambright, C., Parks, L.,...Guillette, L. (2001). Effects of environmental antiandrogens on reproductive development in experimental animals. Hum.Reprod Update, 7(3), 248-264.

Handayani, I. G. K. (2013). Urgensi perlindungan anak di Indonesia (kajian perspektif hukum). Bestuur, 2.

Hastuti, D., Syarief, H., Megawangi, R., Guhardja, S., \& Patmonodewo, S. (2008). Karakteristik keluarga, interaksi ibu-anak, dan pengasuhan serta pengaruhnya pada tumbuh kembang anak di Bogor dan Depok. Media Gizi dan Keluarga, 32(1), 42-55.

Hawley, J. K. (1985). Assessment of health risk from exposure to contaminated soil. Risk Anal, 5, 289-302.

Huebner, E. S. (1991). Correlates of life satisfaction in children. School Psychology Quarterly, 6, 103-111.

Lewis. 1994. Evaluation of methods for monitoring the potential exposure of small children to pesticides in the residential envi-ronment. Arch. Environ. Contamin. and Toxicol, 26, 37-46.

Longnecker, M. P., Klebanoff, M. A., Brock,J. W., Zhou, H., Gray, K. A., Needham, L. L., \& Wilcox, A. J. (2002). Maternal serum level of 1,1 -dichloro- 2,2 -bis ( $p$ chlorophenyl) ethylene and risk of cryptorchidism, hypospadias, and polythelia among male offspring. American Journal of Epidemiology, 155(4), 313-322. 2-15.

Messman-Morre, T., Walsh, K., \& DiLillo, D. (2010). Emotion dysregulation and risky sexual behavior in revictimization. Child Abuse \& Neglect, 34(12), 967-976.

Miserandino, M. (1996). Children who do well in school: Individual differences in perceived competence and autonomy in above- average children. Journal of Educational Psychology, 88, 203- 214.

NRC. (1993). Pesticides In the Diets of Infants and Children. Washington, DC, US: National Academy Press.

Newcombe, H. B., \& McGregor, J. F. (1971). Childhood cancer following obstetric radiography. Lancet, 2(7734), 1151-1152. 11-20.

Pailhe, A., \& Solaz, A. (2006), Employment and childbearing: women bear the burden of the work-family balance. Population and societies, 426.

Papalia, D., \& Olds, S. (2001). Human development (7th ed). New York, US: Mc. Graw Hill.

Parke, R. D., \& Tinsley, B. R. (1981). The father's role in infancy: Determinants of involvement in caregiving and play. In M. E. Lamb (Ed.), The role of the father in child development, 2nd Edition. New York, US: John Wiley \& Sons.

Rickman, M. \& Davidson, R. (1994). Personality and behavior in parents of tempermentally inhibited and unhibited children. Developmental Psychology, 30(3), 346354.

Tadesse, A., \& Asferachew, A. (2008). An assessment of the pesticide use, practice and hazards in the Ethiopian Rift Valley. Africa Stockpiles program, Annex, 6, 61p.

Thompson, S. \& Aked, J. (2009). A guide to measuring children's well-being. Diambil dari www.actionforchildren.org.uk [diunduh 8 Apr 2014]

Trasande, L., Landrigan, P. J., \& Schechter, C. (2005). Public health and economic consequences of methyl mercury toxicity to the developing brain. Environ. Health Perspect. 113(5), 590-596.

Wong, F. K., Cheung, S., Chung, L., Chan, K., \& Chan, A. (2008). Frame-work for adopting a problem-based learning approach in a simulated clinical setting. Journal of Nursing Education, 47(11), 508514.

Zartarian. (1998). Dermal exposure: The missing link. Environ. Sci. and Tech, 134A.

Zweiner \& Ginsburg. (1988). Organophosphate and carbamate poisoning in infants and children. Pediatrics, 81(1), 121-126. 